\title{
RISKS AND DETERMINANTS OF RISK MANAGEMENT STRATEGIES AMONG RURAL CASSAVA-BASED FARMERS IN IMO STATE
}

\author{
C.E. Ahaneku ${ }^{1}$, S.U.O. Onyeagocha ${ }^{2}$, C.C. Eze ${ }^{2}$, N.M. Chidiebere-Mark ${ }^{3}$, G.O. Ellah ${ }^{2}$ and \\ G.I. Isaiah ${ }^{2}$ \\ ${ }^{1}$ Department of Agricultural Economicsand Extension, Nnamdi Azikiwe University, Awka. \\ ${ }^{2}$ Department of Agricultural Economics, Federal University of Technology, Owerri. \\ ${ }^{3}$ Department of Agricultural Economics, Extension and Rural Development, Imo State \\ University, Owerri
}

\begin{abstract}
Cassava-based farmers are faced with a lot of risks and uncertainties and this results to low agricultural output and hinders the rural farmers from pursuing their farming activities as an enterprise. The study assessed the risks and determinants of risk management strategies among rural cassava-based farmers in Imo State. A multistage sampling technique was used in the selection of respondents. Data were collected with the use of structured questionnaire administered to 180 respondents. Multinomial logit regression model was used to determine the factors influencing the choice of risk management strategies among rural cassava-based farmers in the study area. Results of the study showed that the farmers were of middle-age, fairly educated and have average farm size of one hectare. Majority of the farmers identified loss of crop due to disease (76.11\%) and loss due to erosion (73.89\%) as sources of risk farmers were exposed to. Also greater number of the respondents adopted practicing of mixed cropping and planting of disease resistant species as risk management strategies. The result of the study also confirmed that age, gender, educational level and farm income were the major determinants of the farmers' choice of risk management strategies. It was recommended that government should make extension services functional and provide policies that will help boost the socio-economic welfare of farmers as this will significantly propel an increase in the choice effective risk management strategies in the area.
\end{abstract}

Keywords: Risk management, risk management strategies, cassava based farmers.

https://dx.doi.org/10.4314/jafs.v17i2.9

\section{INTRODUCTION}

Cassava (Manihot esculenta Crantz) was introduced into West Africa by the early Portuguese traders in the seventeenth century (Njoku and Banigo 2006). Nigeria is the largest producer of cassava in the world, accounting for $19 \%$ of world production and $35 \%$ of total African production (Sanni et al., 2009). Its production is put at about 52 million metric tonnes a year Journal of the Faculty of Agriculture and Veterinary Medicine, Imo State University Owerri website: www ajol.info 

Volume 17 Number 2, October 2019 pp 100 - 115

(FAO, 2011). Cassava is a very important crop in Nigeria in general, and Imo State in particular. Cassava productions in Imo State have been concentrated in the hands of smallholder farmers (Eze, et al., 2012). Smallholder farmers are those who produce on small-scale bases, not involved in commercial agriculture but produce at a subsistence level.

Cassava-based farmers face a lot of risks and uncertainties. At farm level, the production costs for cassava in Nigeria are high; resource poor farmers have limited resources (capital) to hire labour and to make effective or optimal use of their lands. Risk" and "uncertainty" are two basic terms to any decision making framework. According to Taiwo and Ayanwale (2005); Dismukes (2006) and Salimonu and Falusi (2012) risk refers to imperfect knowledge where the probabilities of the possible outcome are known, and uncertainty exists when these probabilities are not known. Under uncertainty, the decision maker does not know the probability of alternative outcomes. Risk and uncertainty are ubiquitous in agriculture and have numerous sources: the vagaries of weather, the unpredictable nature of biological processes, the pronounced seasonality of production and market cycles, the geographical separation of producers and end users of agricultural products, the unique and uncertain political economy of food and agriculture within and among Nations (Soham and Vikas, 2013). Risk is a central issue that affects many different aspects of people's livelihoods in the developing world (Kouame, 2009). Risk hinders the rural farmers from pursuing their farming activities as an enterprise which therefore threatens food security in the country.

Risk management according to business dictionary is defined as the practice of identifying the potential risks in advance, analyzing them and taking precautionary steps to curb or reduce them. Risk management in agriculture is an essential tool for farmers to anticipate, avoid and react to shocks (OECD, 2011). Managing agricultural risk is particularly important for smallholder cassava growers, who are usually vulnerable to poverty and lack the resources to absorb shocks (Cole et. al., 2008). Proactively, managing risks is the process of looking at the probability of the event occurring, what the potential outcome might be, and how that outcome might change if certain risk management tools were used (Catlett and Libbin, 2007). Risk management helps the farmer to identify, assess and quantify the risk; having clear understanding of all the risks will help measure and prioritize them thereby making proper decisions to reduce losses. Effective risk management reduces the opportunity for finances to be used fruitlessly making sure that all resources are utilized efficiently (Hurley, 2010).

Risk management strategies are defined as the methods applied to remove or reduce partly the effect of factors creating risk in agriculture. To reduce effects of risk or survive in the poor conditions for farm activities, it is necessary to use risk management strategies. The selection of good risk management strategies depends on the farm operator, the financial situation and risk attitudes of the farmer (Korir, 2011). Cassava-based farmers' decisions are subject to risk, much of their income is highly vulnerable to drought, lack of alternatives to rain-fed agriculture, widespread environmental degradation, poor access to commodity market, poor access to Journal of the Faculty of Agriculture and Veterinary Medicine, Imo State University Owerri website: www ajol.info 

Volume 17 Number 2, October 2019 pp 100 - 115

extension services. This has led to huge losses in crops and income of these rural farmers. It therefore becomes important for farmers to obtain accurate cost-effective, risk management strategies on cassava production, processing and marketing of the product to maximize profit. Cassava-based farmers are predominantly small-holders with farms of two hectares and below, produce significant amount of staple crop with virtually no or little fertilizers and improved seeds. They rely mainly on nature (International Fund for Agricultural Development, (IFAD), (2011), Altieri, (2009) Altieri and Koohafkan, (2008), which affects their productivity and thus growth and development of the nation. According to COMESA (2010), Cassava- based agricultural system under a primarily rain-fed system with one growing season using low-input technology is in most areas not going to provide a viable pathway out of poverty. In recent years, a number of researchers (Salimonu and Falusi (2012); OCED (2013); Cervantes-Godoy et al., (2013) and World Bank (2013), have carried out studies on risk management strategies amongst farmers. To reduce effects of risk or survive in the poor conditions for farm activities, it is necessary to use risk management strategies. The selection of good risk management strategies depends on the farm operator, the financial situation and risk attitudes of the farmer (Korir, 2011). In Imo State, empirical evidence remains largely scanty and devoid of in-depth analysis of the effects of socio-economic characteristics of the farmers on the choice of risk management strategies. There is therefore a need to assess risks; choice of risk management strategies and the determinants of risk management strategies among small holder cassava-based farmers. These can help government take policy decisions that can help boost productivity and increase in the farmers' profit. It will also help extension workers on how to educate the farmers. It is against this background and dearth of empirical literature that this study is set to ascertain the determinants of risk management strategies among rural cassava-based farmers as well as determine the socio-economic factors influencing their choice of risk management strategies.

\section{MATERIALS AND METHODS}

The study was carried out in Imo State, Nigeria. The State lies within Latitudes $5^{0} 40^{\mathrm{I}}$ and $7^{0} 5^{\mathrm{I}}$ north and Longitudes $6^{\mathrm{o}} 35^{\mathrm{I}}$ and $8^{\circ} 30^{\mathrm{I}}$ east. The state is selected for this study because of its agrarian status and is well suited for production of arable crops such as cassava, yam, etc. Imo state is bounded on the east by Abia State, on the west by River Niger and Delta State, by Anambra State on the north and Rivers State on the south. The State covers a land area of $7,480 \mathrm{~km}^{2}$ with a population of $3,939,899$ people (NPC, 2006). The State has an average annual temperature of $28^{\circ} \mathrm{C}$, an average annual relative humidity of $80 \%$, average annual rainfall of 1800 to $2500 \mathrm{~mm}$ and an altitude of about $100 \mathrm{~m}$ above sea level (Imo State Agricultural Development Programme, (Imo-ADP), 2010). A multistage sampling technique was adopted in the selection of the respondents. Across each stage a proportionate sampling technique was used to select $1 / 3$ of the LGAs, communities and villages. At the first stage, a proportionate random sampling technique was used to select 9 LGAs from the 27 LGAs in the 3 agricultural zones, 4 LGAs were selected from Owerri zone, 3 and 2 from Orlu and Okigwe zones respectively. At the

Journal of the Faculty of Agriculture and Veterinary Medicine, Imo State University Owerri website: www ajol.info 
second stage; 18, 13 and 10 communities were proportionately selected from the selected LGAs in the 3 Agricultural zones. At the 3rd stage; 20 villages from the selected communities in Owerri zone, 15 and 10 villages from selected communities in Orlu and Okigwe zones, respectively were randomly selected, to give a total of 45 villages sampled for the study. At the final stage, 4 cassava-based farmers were randomly selected from each of the selected villages in the three zones to give a total sample size of 180 farmers for the study. The sample was drawn from the sampling frame compiled with the help of Local Government officials. Primary data were used for the study and were collected by the use of structured questionnaire. The data collected were analyzed using descriptive statistics such as frequency, percentages and multinomial logistic technique.

The MLM Model is shown as

$P(Y i=j)=\frac{\exp (\beta \mathrm{j} \mathrm{xij})}{\left[1+\sum \exp (\beta \mathrm{j} \mathrm{xi})\right]} \mathrm{j}=1,2,3-----6$

For the reference category,

$\operatorname{Pr}(Y i=0)=\frac{1}{\left[1+\sum \exp (\beta \mathrm{j} \mathrm{xi})\right]} \mathrm{j}=0$

Where:

Pij denote the farmer's probability of adopting any of the risk management strategies between $1,2, \ldots 6$ Pio is the probability of being in the reference category.

The explicit function is stated as follows:

$\mathrm{Yi}=\operatorname{In}(\mathrm{Pj} / \mathrm{Po})=\beta_{1} \mathrm{X}_{1}+\beta_{2} \mathrm{X}_{2}+\beta_{3} \mathrm{X}_{3}+\beta_{4} \mathrm{X}_{4}+\beta_{5} \mathrm{X}_{5}+\beta_{6} \mathrm{X}_{6}+\beta_{7} \mathrm{X}_{7}+\beta_{8} \mathrm{X}_{8}+\mathrm{ei} \ldots .$. Eqn. 3.1 .3

$\mathrm{Yi}=$ Adoption of risk management strategy $(\mathrm{i}=1,2, \ldots 6)$

(1) Improved production practice (2) Irrigation (3) Market Oriented Production, (4) Crop Insurance (5) Use of Organized information data (6) Diversification into non-farm activities, and the base category being improved production practice.

Where:

$\mathrm{X} 1=$ age $($ years $)$

$\mathrm{X} 2=$ Sex (Dummy: $\mathrm{i}=$ male, $\mathrm{o}=$ female $)$

$\mathrm{X} 3=$ Educational level (years)

$\mathrm{X} 4=$ Farming experience (years)

X5= Household Size

$\mathrm{X} 6=$ Farm Size $($ ha $)$

Journal of the Faculty of Agriculture and Veterinary Medicine, Imo State University Owerri website: $w w w$ ajol.info 
Journal of Agriculture and Food Sciences

Ahaneku, C.E., Onyeagocha, S.U.O, Eze, C.C., 104 Volume 17 Number 2, October 2019 pp 100 - 115

X7 = Marital Status (Dummy: $i=$ male, $o=$ female)

$\mathrm{X} 8=$ annual Income $(\mathrm{N})$

\section{RESULTS AND DISCUSSION}

\section{Socio-economic Characteristics of the Rural Cassava-based Farmers}

Frequency and percentage distribution of farmers based on their socio-economic characteristics of the rural cassava-based farmers are shown in Table 1 . The result showed that majority of the farmers fell within the age bracket of $51-60$ years, with mean of 57 years. This implied that majority of the farmers in the study area were at their middle age. The result indicated that majority of the respondents $(51.1 \%)$ are females. This implied that cassava production is regarded as a gender enterprise task because of its simplicity in cultivation (Eze, et al.,2012). The result of the marital status of the rural cassava-based farmers showed that majority of the respondents $(91.1 \%)$ are married and most of the respondents $(66.1 \%)$ had family size within the range of $5-8$ persons with the mean of 6 persons. This can be attributed to labour optimization.

The result on level of education of the farmers showed that (47.8\%) of the respondents had formal education with mean of 11 years. From the result, it could be said that farmers in the study area are semi-literate and it is expected that the level of education will contribute significantly to decision making of farmers to risk management strategies. About $38.8 \%$ of the population of the respondents had farm experience of $21-30$ years with mean of 35 years. This showed that the farmers were experienced. The farmer's experience in farming determines the rate of his exposure to risk and the use of risk management strategies. The findings on the farm size showed that $40.6 \%$ of the farmers have farm size within the range of $0.2-0.7$ hectares with mean size of 1.0 hectare. This indicates that the respondents were smallholder farmers. Majority of the farmers $(88.3 \%$ belong to one form of cooperative or the other. Membership of cooperatives is known to confer on entrepreneurs several benefits especially in relating with governmental agencies, financial institutions and non-governmental organizations.

\section{Sources of Risk among Cassava-Based Farmers}

Table 1 show the multiple responses and percentage distribution of farmers by various sources of risk. Results showed that majority $(76.11 \%)$ of the rural cassava-based farmers reported loss of crop due to diseases while (73.89\%) identified loss due to erosion. This could be attributed to the flood disaster which occurred in most part of Nigeria, Imo State inclusive in 2012. This implied that farmers in the study area are bound to have low output which can affect their profit.

\section{Risk Management Strategies Adopted by Cassava-Based Farmers}

Risk management strategies adopted by the rural cassava-based farmers is presented in table 3 . The table showed that majority of the respondents (92.78\%) adopted practicing of mixed

\section{Journal of the Faculty of Agriculture and Veterinary Medicine, Imo State University Owerri} website: www ajol.info 

Volume 17 Number 2, October 2019 pp 100 - 11.5

cropping while $(88.89 \%)$ and $(87.22 \%)$ adopted planting of disease resistant stem and diversification into nonfarm activities. This may be attributed to high rate of loss of crops due to diseases in the area. It also suggests that farmers diversify production because of impending risk and uncertainties. This is in consonant with the findings of Taiwo and Ayanwale (2005) and Nto et al., (2014) who noted that crops diversification is the major risk management strategies of farmers and also in line with Korir (2011) who asserted that off-farm investment is the key risk management farmers usually adopt in the face of impending agricultural risk. Small proportion, (2.87\%) of farmers adopted crop insurance as risk management strategy. The low usage of insurance services can be likened to rural farmers' inability to pay for insurance services or being unaware of it.

\section{Effects of Socio-Economic Characteristics of the Farmers on their Choice of Risk Management Strategies Adopted}

The effects of socio-economic characteristics of farmers on their choice of risk management strategies are shown in Table 2 and 3 respectively.

It shows the influence of the socio-economic characteristics on the risk management strategies which were classified into six categories namely; improved production practices, irrigation, market oriented production, crop insurance, organized information data, diversification into nonfarm employment. The effect of the socio-economic characteristics of farmers on their choice of risk management strategies employed was analyzed using multinomial regression. Multinomial logit regression is a choice model with mutually exclusive categories of dependent variable. Therefore, it is desirable to choose a reference category to compare with a given choice. Hence, improved production practices was chosen as default because improved production practices was the most frequent amongst the choice categories hence comparism of other choices were drawn with respect to the base category. Based on the fact that parameter estimates of multinomial logistic model gives only the direction and not the actual probabilities, marginal effects were used for the interpretation.

The result of the multinomial logit regression model showed that log likelihood was 283.06426.The likelihood ratio Chi Square of 149.59 with a P-value which was significant at 5\% probability level gives the impression that the dependent and independent variables included in the model fits significantly better than an empty model (i.e., a model with no predictors) which indicated that slopes of the coefficients are significantly different from zero and they jointly have significant determinant effects on the choice of the socioeconomic characteristics for a particular strategy adopted. It also means that the model has a good explanatory power. The Pseudo $\mathrm{R}^{2}$ was 0.3805 and this value was considered high enough for providing sufficient explanation about the model. The Pseudo $\mathrm{R}^{2}$ value shows the variance explained by the model and gives a good impression regarding the model's goodness of fit. Previous studies, Zepeda (1990) and Rahji and Fakayode (2009) had reported pseudo $\mathrm{R}^{2}$ values of 0.25 and 0.3145 respectively as representing 
a relatively good-fit for a multinomial logit model. Hence, the pseudo $\mathrm{R}^{2}$ value of 0.3805 in this study is indicative of good fit and the correctness of the estimated model.

The data were tested for the validity of the independence of the irrelevant alternatives (IIA) assumptions by using the Hausman test for IIA. For the Hausman test, the chi-Square $(\chi 2)$ ranged from -3.07 to 0.43 with p-value (1.00), the test failed to reject the null hypothesis of independence of the risk management strategies, suggesting that the multinomial logit (MNL) specification was appropriate to model risk management strategies. Also, this implied that the application of the MNL specification to model the determinants of risk management strategies was justified. The likelihood ratio statistics as indicated by $\chi^{2}=-283.06426$ are highly significant $(\mathrm{p}<0.05)$, this also suggest that the model has a strong explanatory power. The coefficients of the parameter estimates shown only provided the direction of the effect of the independent variables on the dependent variables estimates but do not represent actual magnitude of change or probabilities. The marginal effects and Quasi-elasticity shown in Table 2 were used to measure the change in dependent variable as a result of a unit change in independent variables and their derivation techniques implicitly indicate that neither the sign nor the magnitude of the marginal effects need bear any relationship to the sign of the coefficients used in obtaining them (Greene, 1993; Rahji and Fakayode, 2009).

For irrigation model, the result showed that age, farm experience, household size and marital status had positive significant relationship with the choice of irrigation as risk management strategies relative to choice of improved production practices. For market oriented production, age, educational level and farm experience had positive relationship with the choice of market oriented production relative to improved production practices. Also, age, gender, educational level, farm experience had positive relationship with choice of crop insurance relative to improved production practices. In the choice for organized information data, age, gender, farm experience and farm income had positive relationship with choice of organized information data relative to improved production practices. For the diversification to non-farm employment, age, educational level, farm experience and farm income had positive relationship with choice of diversification to non-farm income relative to choice of improved production practices. According to Rahji and Fakayode (2009), the positive sign implies that the probability of a farmer's choice of other categories relative to the reference group (which in this case is improved production practices) increases as these explanatory variables increase. In other words, the probability that a farmer would adopt other categories of risk management strategies other than the reference group (improved production practices) is higher when the parameter(s) is positive. The negative parameter means that the probability of being in the other choice categories is lower relative to the probability of choosing the reference group. The values of the estimated marginal effects and the quasi - elasticity calculated at the overall sample means following Basant (1997) and Rahji and Fakayode (2009) for the significant variables. The significant variables affect both the probability of choice amongst the management strategies adopted. It is

Journal of the Faculty of Agriculture and Veterinary Medicine, Imo State University Owerri website: www ajol.info 

Volume 17 Number 2, October 2019 pp 100 - 11.5

noteworthy that estimates not significantly different from zero indicate that the regressor or explanatory variable concerned does not affect the probability or utility derivable in choice decision relative to the reference group into the other five management strategies.

The result of the Quasi-elasticity was presented in Table 3 below. The positive value of quasielasticities indicates that $1 \%$ increment in the explanatory variable results to a percentage increment in the choice of a risk management strategy relative to reference category while negative quasi-elasticities implies a percentage decrease in the choice of a risk management strategies relative to reference category as a result of $1 \%$ increment in the explanatory variable. Also, a value greater than unity indicates elastic values which implies that $1 \%$ change in the explanatory variables result in a more proportionate change in the choice of a particular strategy relative to reference category and a value that is lesser than unity indicates inelastic values which means that $1 \%$ change in explanatory variable result in a lesser proportionate change in the choice of a particular strategy relative to reference category.

Based on the significant variables of the choice of irrigation, quasi-elasticity of age of the farmers was $-4.1994(p<0.05)$ which means it is elastic, significant at 5\% statistical level and that $1 \%$ increment in the age of the farmer would results in a more proportionate reduction in his choice of irrigation relative to improved production practices by $419.9 \%$, the educational level which value was $-0.9552(\mathrm{p}<0.01)$ is inelastic and significant at $1 \%$, implies that $1 \%$ increment in educational level of the farmer results to a less proportionate reduction in the choice of irrigation relative to improved production practices by $95.52 \%$. the quasi-elasticity of farm experience, farm size and farm income were $0.9976(\mathrm{p}<0.01), 0.9491(\mathrm{p}<0.01)$ and $0.9430(\mathrm{p}<0.01)$ which indicate significant at $1 \%$ and inelastic to choice of irrigation and $1 \%$ increment in these explanatory variables result to a lesser proportionate increment in the choice of irrigation relative to improved production practices by $99.76 \%, 94.91$ and $0.94 .30 \%$ respectively. The quasielasticity of marital status is 0.84553 ( $p<0.1$ ), more married farmers choose irrigation than single individuals relative to improved production practices.

For choice of market oriented products; age, educational level, farm experience and farm income had quasi-elasticity of $-0.0834(\mathrm{p}<0.05), 0.3671(\mathrm{p}<0.01),-0.8443(\mathrm{p}<0.01)$ and -0.5055 $(\mathrm{p}<0.01)$. This indicated that these explanatory variables were inelastic and significant at $5 \%$ statistical level. A percentage increases in age, educational level, farm experience and farm income results in lesser proportionate of $8.34 \%$ decrease, $36.71 \%$ increase, $84.43 \%$ increase and $50.55 \%$ decrease in the choice of market oriented product relative to improved production practices respectively.

The quasi-elasticities of educational level, farm size and farm income were $1.0305(\mathrm{p}<0.1)$, $0.7135(\mathrm{p}<0.05)$ and $-0.9205(\mathrm{p}<0.05)$ respectively. This means that educational level is elastic and $1 \%$ increase in years of educational level result to a more proportionate increase by $103.05 \%$ in the choice of crop insurance strategy rather than improved production practices. Both farm

Journal of the Faculty of Agriculture and Veterinary Medicine, Imo State University Owerri website: www ajol.info 
size and income were inelastic and it indicated that $1 \%$ increase in farm size and income results to lesser proportionate $71.35 \%$ increase and $92.05 \%$ decrease in choice of crop insurance relative to improved production practices respectively.

For Organized information category; age, gender, educational level, and farm income were $1.9976(\mathrm{p}<0.1), 0.3492(\mathrm{p}<0.1),-1.3531(\mathrm{p}<0.01)$ and $0.9337(\mathrm{p}<0.01)$. This indicated that age and educational level were elastic and $1 \%$ increases leads to $199.76 \%$ increase and $135.31 \%$ decrease in choice of use of organized information data relative to improved production practices. Gender and farm income were inelastic and $1 \%$ increase results to $34.92 \%$ increase and $93.37 \%$ increase in choice of organized information relative to improved production practices.

In the diversification to non-farm income and off farm employment option, age, gender and farm size had quasi-elasticity values of $1.9096(\mathrm{p}<0.1),-0.3720(\mathrm{P}<0.05)$ and $-0.9285(\mathrm{p}<0.01)$ which indicated that choice of diversification to non-farm employment has elastic response to age but inelastic to gender and farm size at $10 \%, 5 \%$ and $1 \%$ statistical level respectively. This implies that $1 \%$ increase in age and farm size results to $190.96 \%$ increase and $92.85 \%$ decrease in choice of non-farm employment relative to improved production practices relatively. It also shows that male farmer has a $37.20 \%$ higher choice of diversification to non-farm employment than female individuals relative to improved production practices.

\section{CONCLUSION AND RECOMMENDATION}

Cassava-based farmers face a lot of risks and uncertainties; especially in Imo State, farmers are compelled to make decisions based on imperfect information and knowledge. This result in low agricultural output and hinders the rural farmers from pursuing their farming activities as an enterprise. The study estimated the determinants of risk management strategies among the rural cassava-based farmers in the study area. Based on the result of the findings, the study concluded that the cassava-based farmers were mainly middle aged, married, experienced, smallholder farmers and highly prone to risk as majority $76.11 \%$ of the rural cassava-based farmers reported loss of crops due to diseases and $73.89 \%$ reported loss due to erosion. The empirical results from marginal effects and quasi elasticity confirmed that age, gender, educational level and farm income were the major determinants of the farmers' choice of risk management strategies. To this effect, efforts should be made by the government to promote functional extension services and provide policies that will help boost the socio-economic welfare of farmers as this will significantly propel an increase in the choice effective risk management strategies in the area. Diversification into non-farm investment should be encouraged among farmers in the area as it reduces risks by increasing resistance and offsetting the seasonal nature of agricultural income.

Journal of the Faculty of Agriculture and Veterinary Medicine, Imo State University Owerri website: www ajol.info 


\section{REFERENCES}

Altieri, M (2009). Agro ecology small farms and food Sovereignty. Monthly Review. 61(3): 102113.

Altieri, M.A. and Koohafkan, P. (2008). Enduring farms: climate change, Smallholders and traditional farming communities. Environment and Development Series No. 6. Third World Network, Penang.

Basant R (1997). Technology strategies of large enterprises in Indian industry: Some explorations. World Development, 25(10): 1683-1700

Catlett, LB, Libbin, JD (2007). "Risk Management in Agriculture: A Guide to Futures, Options and Swaps", New York. Thomson Delmar Learning Clifton Park.

Cole, S., Chattopadhyay, R., Hunt, S., Tobacman, J. and Topalova. P. (2008). Weather Insurance, Price Information, and Hedging: Helping the Poor Manage Risks. BASIS Brief. Madison: BASIS CRSP

Common Market for Eastern ad South Alliance for Community Trade in Southern Africa (COMESA) (2010). Opportunities and Challenges for strengthening Staple Food Market in Eastern and Southern Africa. Http://www.aec.mus.edu/Fs2/gisama/index.html

Cervantes-Godoy, d., Kimura, S. and J. Athon (2013). Smallholder Risk Management in Developing Countries, OECD, Food, Agriculture and Fisheries Papers, OECD publishing.

Dismukes, R. (2006). Farm Risk Management; Briefing/risk Management

Eze, C.C., Ibekwe, U.C., Chiediebere-Mark, N.M., Chikezie, C., Okparadim, G.I. and Amadi, S.N. (2012). Resource Use Efficiency of Smallholder Farmers in Multiple Cropping Systems in Owerri Agricultural Zone of Imo State. A paper delivered at the $50^{\text {th }}$ Annual Conference of the Nigerian Association of Agricultural Ecoomist held at Obafemi Awolowo University, Ile-Ife, $25^{\text {th }}-27^{\text {th }}$ September, 2012.

Food and Agriculture Organization FAO (2011). FAOSTAT Database

Greene, W.H. (1993). Econometric analysis, third edition. Prentice Hall Upper Saddle River, New Jersey.

Hurley, T.M (2010). 'A Review of Agricultural Production Risk in Developing Agriculture'. Food and Agricultural Organization of the United India. Journal of Social and Economic Development 3(2), 208-215

IITA (2011). R4D Review. Issue 7, September 2011, 1-64

International Fund for Agricultural Development (IFAD). 2011. Rural poverty report. New realities, new challenges: New opportunities for tomorrow's generation. Rome, Italy.

Journal of the Faculty of Agriculture and Veterinary Medicine, Imo State University Owerri website: www ajol.info 
Journal of Agriculture and Food Sciences

Ahaneku, C.E., Onyeagocha, S.U.O, Eze, C.C., 110

Volume 17 Number 2, October 2019 pp 100 - 11.5

Chidiebere-Mark, N.M., Ellah, G.O. and Isaiah G.I.

Imo State Government Retrieved, 27 $7^{\text {th }}$ July 2010

Kouame, E.B. (2009). Risk, Risk Aversion and Choice of Risk Management Strategies by Cocoa Farmers in Western Cote D'Ivoire, University of Cocody-AERC Collaborative PHD Programme

Korir, L.K (2011). Risk Management Among Agricultural Households And the Role of Off-farm Investments in Uasin Gishu County, Kenya; Unpublished M.Sc thesis, Egerton University, Kenya

National Population Commission (NPC). (2006). National Population Commission Landmass compiled from NPC Report, 1991 and Field Reports.

Njoku, B.A. and E.O. Banijo (2006). Physico - Chemical Properties of Precooked Cassava (Manihot esculenta Cratz) Flour Prepared by Adaptation of a Traditional Process, Nigerian Food Journal, Nigerian Institute of Food Science and Technology, 24: 98-106

Nto, P. O.O., Mbanasor, J.A., Nto, C. P. O. and Osuala, A. E. (2014). Evaluation of Risk Management Practices in Rice Production in Abia State, Nigeria. Swiss Journal of Management \& Business Studies, 1(1): 1-10

Organization for Economic Co-operation and Development (OECD). (2011). Managing Risk in Agriculture: Policy Assessment and Design, OECD Publishers Pairs;

Rhaji, M.A.Y and Fakayode, S.B (2009) A Multinomial Analysis of Agricultural Credit Rationing by Commercial Banks in Nigeria. International Research Journal of Finance and Economics Issue 24:90-100.

Salimonu, K.K and Falusi, A.O. (2012). Sources of Risk and Management Strategies among Food Crop Farmers in Osun State, Nigeria; Africa Journal of Food Agriculture, Nutrition and Development; 9(7), 1591-1605

Sanni L.O., Onadipe O.O., Ilona P, Mussagy M.D., Abass, A. and Dixon A.G.O (2009). Successes and Challenges of cassava enterprises in West Africa: a case study of Nigeria, Benin and Sierra Leone. IITA, Ibadan, Nigeria.19 pp.

Soham, S and Vikas, C. (2013). ICT Applications for Agricultural Risk Management; Economic and Sector work; World Bank Project, 2013; www.worldbank.com

Taiwo, A and Ayanwale, A.B. (2005). Risk Management Strategies in Onion Production in Kebbi State of Nigeria; J. Soc. Sci., 10(1): 1-8

World Bank (2013). Swaziland: Reducing poverty through shared growth. Poverty World. Working Paper for Harvest Choice Pp55. www.harvestchoice.org

Zepeda L 1990. Adoption of Capital versus Management Intensive Technologies. Canadian Journal of Agricultural Economics, 38:457-469.

Journal of the Faculty of Agriculture and Veterinary Medicine, Imo State University Owerri website: www ajol.info 
Ahaneku, C.E., Onyeagocha, S.U.O, Eze, C.C., 111

Journal of Agriculture and Food Sciences Chidiebere-Mark, N.M., Ellah, G.O. and Isaiah G.I.

Volume 17 Number 2, October 2019 pp 100 - 115

\section{APPENDIXES}

Table 1: Frequency Distribution of the farmers' socio-economic characteristics

\begin{tabular}{lrr}
\hline Socio-economic characteristics & Frequency & Percentage \\
\hline Age & & \\
$31-40$ & 7 & 3.9 \\
$41-50$ & 35 & 19.5 \\
$51-60$ & 71 & 39.4 \\
6170 & 58 & 32.2 \\
Above & 9 & 5 \\
Total & 180 & 100 \\
Mean & 57years &
\end{tabular}

\section{Gender}

Male

$88 \quad 48.9$

Female

92

51.1

Total

180

100

\section{Marital Status}

Single

Married

Total

\section{Household size}

1- 4

5- 8

9- 12

Total

Mean

\section{Years of formal Education}

1- 6

7-12

13- 18

Total

Journal of the Faculty of A riculture and Veterinary
31

17.2

$16 \quad 8.9$

$164 \quad 91.1$

$180 \quad 100$

44

24.5

119

66.1

17

9.4

180

100

$86 \quad 47.8$

$63 \quad 35$

$180 \quad 100$ 6persons

Journal of the Faculty of Agriculture and Veterinary Medicine, Imo State University Owerri website: www ajol.info 


\section{Farming Experience}

1- 10

11- 20

21- 30

31- 40

41- 50

Total

Mean

Farm Size

0.02- 0.70

$0.71-1.30$

1.31- 1.90

1.91- 2.50

Total

Membership of Association

Cooperative Society

None

2.8

30

38.8

23.3

100

31

17.2

12

6.6

180

100

Total

Source: Field survey Data, 2016

Table 2: Distribution of Farmers by Sources of Risk

\begin{tabular}{lrr}
\hline Sources of Risk & Frequency* & \% Distribution \\
\hline Loss of crop to diseases & 137 & 76.11 \\
Loss due to erosion & 133 & 73.89 \\
Loss due to lack of adequate credit & 131 & 72.78 \\
Loss due to low market value & 129 & 71.67 \\
Loss due to theft & 125 & 69.44 \\
Fire outbreak in farmland & 123 & 68.33 \\
Loss due to pests attack & 118 & 65.56
\end{tabular}

Journal of the Faculty of Agriculture and Veterinary Medicine, Imo State University Owerri website: www ajol.info 
Loss due to herds men

Loss due to lack of storage facilities

Loss of crop due to poor processing facilities

103

Loss due to lack of market to sell cassava

Loss due to high interest rate 76

Loss due to insincerity of business associates

Loss due to land conflicts

Flood (excess of water on farmland)

Loss due to out-dated asset

Drought (excessive dry weather)

Loss of crop due to sickness of family member

Loss due to government laws

Source: Field Survey Data, 2016

Table 3: Percentage distribution of Respondents by Risk Management Strategies

\begin{tabular}{lcr}
\hline Risk Management Strategies & Frequency* & \% Distribution \\
\hline Practice of mixed cropping & 167 & 92.78 \\
Planting of disease resistance stem & 160 & 88.89 \\
Diversification into non-farm activities & 157 & 87.22 \\
Fertilizer application & 153 & 85.00 \\
Mixing cropping & 146 & 81.11 \\
Mixed farming & 130 & 72.22 \\
Value addition to cassava products & 125 & 69.44 \\
Clearing of bush around farm borders & 124 & 68.89 \\
Change in planting dates & 120 & 66.67 \\
Involvement in thrift and cooperative societies & 113 & 62.78 \\
Use of insecticide & 103 & 57.22 \\
Making of bunds and channels & 94 & 52.22 \\
\hline
\end{tabular}

Journal of the Faculty of Agriculture and Veterinary Medicine, Imo State University Owerri website: www ajol.info 
Journal of Agriculture and Food Sciences

Ahaneku, C.E., Onyeagocha, S.U.O, Eze, C.C., 114

Volume 17 Number 2, October 2019 pp 100 - 11.5 Chidiebere-Mark, N.M., Ellah, G.O. and Isaiah G.I.

Use of herbicide 92

Proper record keeping

Use of modern planning \& management tools

Use of meteorological information

Contract cassava production

Irrigation during drought

Use of organized information/data

Source: Field Survey Data, 2016

Table 4: Coefficients and Marginal Effects of the Determinants of Choice of Risk Management Strategies Adopted by cassava based farmers

\begin{tabular}{|c|c|c|c|c|c|c|c|c|c|c|}
\hline & Irrigation & & $\begin{array}{l}\text { Market } \\
\text { oriented } \\
\text { prodn }\end{array}$ & & $\begin{array}{l}\text { Crop } \\
\text { insurance }\end{array}$ & & $\begin{array}{l}\text { Organized } \\
\text { information } \\
\text { data }\end{array}$ & & Diversified & \\
\hline Variables & Coeff & dy/dx & Coeff & $d y / d x$ & coeff & dy/dx & Coeff & dy/dx & coeff & dy/dx \\
\hline Age & 0.0904 & -0.0003 & 0.0426 & -0.0103 & 0.0867 & 0.0094 & 0.0642 & 0.0131 & 0.0778 & 0.0064 \\
\hline Gender & -0.2576 & -0.0103 & -0.1610 & -0.0107 & 0.1957 & 0.0247 & 0.6012 & 0.1104 & -0.8740 & -0.1457 \\
\hline Education & -0.5060 & -0.0230 & 0.0702 & 0.0198 & 0.0898 & 0.0096 & -0.0158 & -0.0065 & 0.0372 & 0.0321 \\
\hline Farm exp & 0.1177 & 0.0097 & 0.0454 & -0.0013 & 0.1188 & 0.0054 & 0.0369 & -0.0022 & 0.0918 & 0.0878 \\
\hline Hh size & 0.0486 & 0.0090 & -0.1093 & -0.0596 & -0.2097 & -0.0106 & -0.1153 & -0.0259 & -0.1130 & -0.0069 \\
\hline Farm size & -0.1143 & 0.0014 & -0.2272 & -0.0807 & -0.0790 & 0.0744 & -0.2159 & -0.0126 & -0.1874 & -0.0901 \\
\hline M. status & 1.1510 & 0.1007 & -0.6896 & -0.0964 & -0.8099 & -0.0441 & -0.3882 & -0.0201 & -0.3212 & -0.0121 \\
\hline Farm inc. & $5.29 \mathrm{e}-08$ & $9.30 \mathrm{e}-09$ & $-3.96 e-07$ & $-7.13 e-08$ & $-1.95 e-06$ & $-1.50 e-07$ & $2.47 e-08$ & $1.57 \mathrm{e}-08$ & $8.35 e-07$ & $2.75 \mathrm{e}-07$ \\
\hline
\end{tabular}

Reference Category

Number of Observation

Pseudo $\mathrm{R}^{2}$

LR Chi Square

Prob.> chi2

Log likelihood

Improved production practices

180

0.3805 lol

149.59

0.0424

$\mathrm{Chi}^{2}$ for IIA ranges from -3.07-0.43

Source: Computed Results from STATA 13 software, 2016

LR chi2(40) = 149.59

Journal of the Faculty of Agriculture and Veterinary Medicine, Imo State University Owerri website: www ajol.info 
Journal of Agriculture and Food Sciences

Ahaneku, C.E., Onyeagocha, S.U.O, Eze, C.C., 115

Volume 17 Number 2, October 2019 pp 100 - 115

Chidiebere-Mark, N.M., Ellah, G.O. and Isaiah G.I.

Table 3: Quasi-elasticities of the Determinants of Risk Management Strategies Adopted by the Farmers

\begin{tabular}{|c|c|c|c|c|c|c|c|c|c|c|}
\hline \multirow[b]{2}{*}{ Variables } & \multicolumn{2}{|c|}{ Irrigation } & \multicolumn{2}{|c|}{$\begin{array}{c}\text { Market oriented } \\
\text { production }\end{array}$} & \multicolumn{2}{|c|}{$\begin{array}{l}\text { Crop } \\
\text { insurance }\end{array}$} & \multicolumn{2}{|c|}{$\begin{array}{c}\text { Organized } \\
\text { information data }\end{array}$} & \multirow{2}{*}{$\begin{array}{l}\text { Diversified } \\
\text { Eyex }\end{array}$} & \multirow[b]{2}{*}{$\mathbf{z}$} \\
\hline & Eyex & $\mathbf{Z}$ & Eyex & $\mathbf{Z}$ & Eyex & $\mathbf{Z}$ & Eyex & $\mathbf{Z}$ & & \\
\hline Age & -4.1994 & $-2.27 * *$ & -0.0834 & $-2.50 * *$ & 2.2903 & 1.33 & 1.9976 & $1.70 *$ & 1.9096 & $1.72 *$ \\
\hline Gender & -0.0706 & -0.26 & -0.0234 & -0.15 & 0.1510 & 0.59 & 0.3492 & $1.77 *$ & -0.3720 & $-2.08 * *$ \\
\hline Education & -0.9552 & $-4.56 * * *$ & 0.3671 & $7.70 * * *$ & 1.0305 & $1.86^{*}$ & -1.3531 & $-3.05 * * *$ & 0.0960 & 0.24 \\
\hline $\begin{array}{l}\text { Farm } \\
\text { experience }\end{array}$ & 0.9976 & $2.64 * * *$ & -0.8443 & $-3.24 * * *$ & 0.5058 & 1.34 & -0.1079 & -0.30 & 0.3034 & 1.25 \\
\hline $\begin{array}{l}\text { Household } \\
\text { size }\end{array}$ & 0.7567 & 0.93 & -0.1937 & -0.44 & -0.7974 & -1.05 & -0.2296 & -0.41 & -0.9159 & -1.84 \\
\hline Farm size & 0.9491 & $2.99 * * *$ & -0.2253 & -1.14 & 0.7135 & $2.54 * *$ & -0.1979 & -0.80 & -0.9285 & $-4.7 * * *$ \\
\hline M. status & 0.8453 & $1.87 *$ & -0.2590 & -1.43 & -0.3312 & -1.09 & -0.0782 & -0.34 & 0.0380 & -0.19 \\
\hline $\begin{array}{l}\text { Farm } \\
\text { income }\end{array}$ & 0.9430 & $3.22 * * *$ & -0.5055 & $-2.64 * * *$ & -0.9205 & $-2.37 * *$ & 0.9337 & $4.36 * * *$ & 0.3014 & 1.59 \\
\hline
\end{tabular}

Eyex $=$ Quasi-elasticities,

Z-tab are 1.64, 1.96 and $2.57 @ 10 \%, 5 \%$ and 1\% level of significance respectively.

$*, * *$ and $* * *$, significant at $1 \%, 5 \%$ and $10 \%$ respectively.

Source: Computed Results from STATA 13 software, 2016

Journal of the Faculty of Agriculture and Veterinary Medicine, Imo State University Owerri website: www ajol.info 